\title{
A Happy Marriage: Academia, Professional and Scientific Associations
}

\author{
Alfonso Díez Minguela* and $M^{\mathrm{a}}$ Ángeles Pons Brias*
}

* Universitat de València

\begin{abstract}
This paper advocates for a greater integration between Higher Education and Professional and Scientific Associations (PSAs). With the development and adoption of Information and Communication Technologies (ICTs), the costs associated with the collection, storage, processing and transmission of information have been reduced. Eventually, the supply of information has boomed. However, more does not necessarily imply better. Free online resources can enhance the learning process, but the lack of quality controls is still a major concern. Additionally, learning demands some degree of organisation and structure. We argue that Higher Education can potentially benefit from a closer relationship with PSAs. In doing so, we introduce the Spanish Economic History Association efforts to organise and prepare high-quality teaching resources. Our brief discussion could provide a route-map for other PSAs.
\end{abstract}

Keywords: Online resources; Professional associations; Higher Education

\section{Introduction}

On September 15, 2008, a well-established investment bank, Lehman Brothers, filed for bankruptcy. Although the financial crisis had already begun, the sudden collapse of the fifth largest investment bank in the world was an eye-opener to many people. The unexpected was occurring, and few had foreseen it. However, the 2008 financial crisis opened up further opportunities for some. As Barry Eichengreen put it in the 2011 Presidential address to the Annual Meeting of the Economic History Association: "This has been a good crisis for economic history.... Journalists, market participants, and policy makers all turned to history for guidance on how to react to this skein of otherwise unfathomable events" (Eichengreen, 2011). A year earlier, Vicky Price, then Joint Head of the Government Economic Service (GES), had argued that, "for the economist, history remains the laboratory through which we are best able to seek to understand how different policies might impact on economic performance. The recent global financial crisis in particular has reminded us how analysis of past periods of economic history can be invaluable in informing contemporary policy questions" (in Crafts et al., 2010).

Although economics had "missed the boat in 2008”, as Carlin (2013) said, the general public demanded an explanation, and a subsequent plan of action. What caused the 2008 financial crisis? What could be done to prevent it? What was to be done? More notably, the study of economic history gained momentum or simply, the demand for economic history increased. For example, a group of economists launched the CORE project (URL: http://core-econ.org/) to promote a new curriculum in economics where economic history plays a central role. Barry Eichengreen, a distinguished economic historian, became a media mogul in the United States. More than a few journalists, policy-makers, professional and academic economists, students and enthusiasts, are looking at the past to better understand the present. Moreover, with the Twenty-First century came the rapid development and diffusion of Information and Communication Technologies (ICTs). By ICTs, we simply refer to Internet, PCs and laptops, mobile 
phones and tablets, and software packages capable of collecting, storing, processing, transmitting and presenting information. Clearly, ICTs have greatly reduced the costs associated with accessing information, which eventually opened up new opportunities in education.

a) Before ICTs

RESTRICIED ACCESS

University degree

- Short courses

b) After ICIs

RESTRICTED ACCESS

University degree

Short course

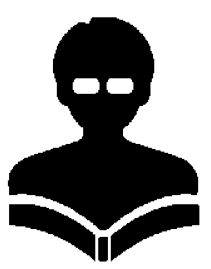

FREE ACCESS

- Public library

FREE ACCESS

Online courses

Online resources (i.e. blogs, webs)

Public library

Figure 1. ICTs and the supply of knowledge

Figure 1 illustrates the opportunities that an individual enjoys in a context before/after ICTs. Before ICTs, knowledge was mainly transmitted via university degrees and/or short courses organised by either academics or professionals. Additionally, books and academic journals were the main sources. ICTs have thus facilitated a greater supply of information. Online resources (academic and non-academic articles; blogs, courses, websites) provide a wider range of tools in the learning process, and in most cases are free. But, how reliable are these? More quantity does not necessarily imply high quality. In fact, the lack of quality controls appears to be a major concern. Moreover, the learning process requires structure and organisation. For this, several institutions have launched Massive Open Online Courses (MOOCs). MOOCs are usually openaccess courses with a proper structure, and materials such as lecture notes, reading lists, and problem sets. Additionally, MOOCs provide students with the opportunity to regularly interact with lecturers or teaching assistants. Therefore, online courses have quality control mechanisms and a basic structure. However, the completion rates hardly reach $20 \%$ (Jordan, 2013). In this brief paper, we propose an approach to balance demand and supply within the traditional context of university degrees: Professional and Scientific Associations (PSAs).

University degrees and short courses provide quality controls and structure, but what if the expertise does not entirely match with the demand for knowledge? For example, suppose there is no faculty expert on the history of financial crises. Under these conditions, there are numerous alternatives. First, doing nothing, hence the demand remains unmatched. Second, there could be faculty openings. Third, if hiring is not viable, those faculty members responsible for organising the course will incur into an extra cost, unless guidance and reliable materials are available. In this paper, we argue that Professional and Scientific Associations (PSAs) could and should play a greater role in Higher Education. 
Traditionally, PSAs were created to promote and support excellence in a particular discipline. The Royal Society, founded during the second half of the 1600s, was aimed at encouraging "the development and use of science for the benefit of humanity". Since then, the number of Professional and Scientific Associations (PSAs) has boomed. Notwithstanding the crucial role played by these associations or clubs in the dissemination of frontier knowledge and values, modern times call for further action. In the United States, the American Economic Association (AEA) offers online resources, while the Economic History Association (EHA) has a website with articles and other materials prepared by broad bunch of experts. In some cases, these articles have been peer-reviewed. In the United Kingdom, the Economic History Society (EHS) also provides online resources, e.g. podcasts. Interestingly, the Bank of England and the Federal Reserve Bank of St. Louis offer a great amount of educational resources too. Then, what role should PSAs play in Higher Education? Should PSAs be responsible for quality control?

In this brief paper we advocate for a greater integration between Higher Education and PSAs. We firmly believe that PSAs could coordinate efforts across researchers. In fact, PSAs could bridge the gap between frontier research and Higher Education. High quality teaching materials can be produced and disseminated. Recent developments can be easily incorporated, thereby linking frontier research and teaching. To motivate our claim, we first introduce our own personal experience at the Universitat de València. Then, we present the Spanish Economic History Association case.

\section{Economic History at the Universitat de València}

The Área de Historia e Instituciones Económicas at the Universitat de València has always made a great effort to promote the study of economic history. In 2010-11, the Facultad de Economía established several new degrees: Business Administration (GADE); Economics (GECO); Finance and Accounting (GFYC) and International Business (GIB). The Área de Historia e Instituciones Económicas or the Economic History Group (EH-Valencia) is in charge first-year courses such as World Economic History and Spanish Economic History (GECO), World Economic and Business History in (GADE; GFYC), and Geopolitics and Globalisation (GIB). Moreover, EHValencia also runs optional four-year courses.

Last summer, EH-Valencia published an up-to-dated world economic history book, which was accompanied by online teaching materials (Palafox, 2014). Our initial aim was to supply students with a well-structured, easy-to-read textbook. Moreover, our economic history courses show students how economic analysis allows us to better understand the past. Furthermore, EH-Valencia has launched an online platform (website; blog; facebook; twitter) too. Our objectives were threefold: (i) To encourage the study of economic history; (ii) To introduce students into major topics and debates; (iii) To promote students' abilities in terms of analysis and discussion. For example, within the EH-Valencia facebook and twitter accounts, students can easily find online resources (web links) related to the main topics explained in the lectures. This has encouraged the interaction between students and lecturers in the classroom. 
There are other platforms within economic history in Spain. Our colleague at the Universidad Pablo de Olavide (UPO), Fernando Ramos Palencia, launched a Blog on Historia Económica, Globalización y Desarrollo/Economic History, Globalisation and development, with numerous entries and a great bunch of teaching resources. There are other blogs, but mostly research-oriented, e.g. Juan Flores (University of Geneve) with other colleagues launched a blog on Past and Present of the World economy. Personal web pages are also another source of knowledge. In these, authors provide their personal opinions and materials, which are selected according to the courses taught or their research expertise. Table 1 summarises the online opportunities available. All in all, the supply of information exceeds the capacity that an individual or a group of teachers have to evaluate and organise.

Table 1. Online resources by type, purpose and main client

\begin{tabular}{|l|cc|}
\hline & \multicolumn{1}{c}{$\begin{array}{c}\text { Personal and } \\
\text { Departmental websites }\end{array}$} & PSAs websites \\
\hline Main purpose & Research \&Teaching & Research \&Teaching \\
\cline { 1 - 3 } & & \\
Main client & Academics Students & Academics
\end{tabular}

Therefore, PSAs could provide greater uniformity and homogeneity. Moreover, by selecting and classifying educational online resources, PSAs could guarantee a highquality standard. Even more, PSAs could create a discussion forum for teaching and educational purposes. In this line of thinking, we would like to present and discuss the active role played by the Asociación Española de Historia Económica (AEHE) in the development of online teaching materials. Although this is a just a simple case, it can easily illustrate how PSAs could participate more actively in Higher Education.

\section{The Spanish Association of Economic History}

The Spanish Association of Economic History or Asociación Española de Historia Económica (AEHE) was founded in 1972. Since then, it has promoted research and teaching related to economic history. The AEHE organises a national congress every three-four years to encourage the exchange of frontier research in economic history. The last one was held in Madrid on September 4-5, 2014. In 2005, the academic journal Investigaciones de Historia Económica was launched too. In addition, several initiatives have recently been introduced to promote excellence in teaching and research. One of these was the Sección de Docencia or Teaching Section (URL: http://www.aehe.net/docencia.html). This portal is free, and is currently organised by Elena Catalán Martínez (Universidad del País Vasco) and Miguel Ángel Bringas (Universidad de Cantabria). Pablo Gutiérrez González (Universidad de Sevilla) and Alfonso Díez Minguela (Universitat de València) have also collaborated.

The Teaching Section has four main goals: (a) To provide further information about the discipline of economic history across Spanish universities (i.e. syllabus); (b) To supply educational and teaching resources related to the discipline; (c) To encourage the use of novel teaching methodologies; (d) To encourage discussion forums among 
lecturers. Figure 2 shows the main organisation of the Teaching Section. First, GUÍAS DOCENTES include the available course syllabus across Spanish universities by region, whereas MANUALES provides information on the main textbooks by subject. The front cover and index of these textbooks have been scanned and uploaded as guidance for prospective teachers. CURSOS EN ABIERTO and MATERIAL AUDIOVISUAL is a collection of online courses, videos, films, and pictures related to economic history. MOOCs have also been included in the former one.

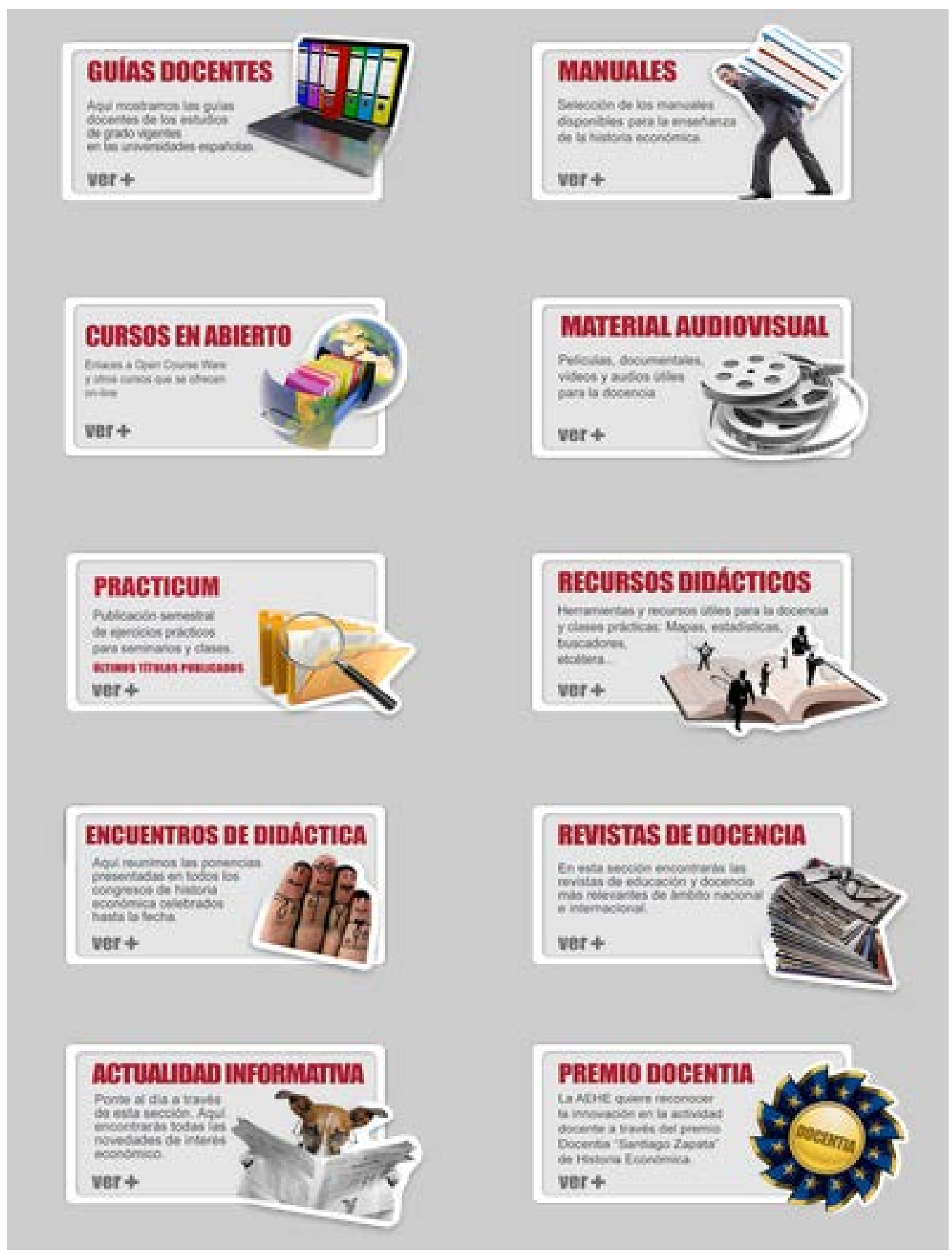

Figure 2. The Teaching Section, Spanish Economic History Association 
One of the most interesting is PRACTICUM, where several teachers have prepared online materials for a specific topic. All these have been properly peer-reviewed by an Advisory Board, which acts as a quality control mechanism. Furthermore, teachers are also researchers, and these materials are closely related to their interests. This is an example of how a greater integration between Higher Education and PSAs could potentially benefit Higher Education. Moreover, biographies, databases, maps and list of teaching tools can be found in RECURSOS DIDACTICOS. ENCUENTROS DE DOCENCIA and REVISTAS DE DOCENCIA mainly refer to the series of events organised by the Spanish Economic History Association to promote the teaching of economic history, and a list of journal on Higher Education in social science. Press articles, special issues, blogs and websites of interest are organised in ACTUALIDAD INFORMATIVA. Finally, the Spanish Economic History Association also awards a prize, the Docentia Prize, to individuals or groups for their outstanding contribution to the teaching in economic history.

There is little doubt that this Teaching Section has had a tremendous impact within the discipline. But, amassing and organising all these resources is costly. Each voluntary contribution needs to be reviewed, thus a committee has been created. Free riding is another major limitation. Although the Spanish Economic History Association has achieved a good deal of participation, coordinating reviewers and encouraging new entries has required a great commitment by the organisers. Finally, to maintain and update online resources is costly too. This, in turn, is one of the main problems of the Teaching Section. Whether or not funds will be available to carry on will depend upon its financial capacity.

Despite of the limitations, we believe that the Spanish Economic History Association provides evidence that PSAs could be the way forward. Since PSAs have as ultimate goal to promote and support excellence in a given discipline, and the vast amount of available information exceeds the capacity of an individual or small group, PSAs could play a role of intermediation and bring up-to-date frontier research to the class.

\section{Conclusions}

With the development and adoption of Information and Communication Technologies (ICTs), the costs associated with the collection, storage, processing and transmission of information have been reduced. Eventually, the supply of information has boomed. These online resources provide a wider range of tools in the learning process, but more does not imply better. For this reason, we advocate for a greater integration of Higher Education and Professional and Scientific Associations (PSAs). With ICTs, several PSAs have greatly increased curriculum-linked online materials, but mostly for primary and secondary education. For example, the Royal Society in the United Kingdom organizes Summer Science Exhibitions and provides teaching resources in its recently developed website: Invigorate. Why not marrying Academia with PSAs to enhance teaching in Higher Education? Teaching materials could be reviewed, organised and structured. To further support our claim, we introduce the Spanish Economic History Association effort to promote the teaching of economic history. Although the Teaching Section can be greatly improved, we regard it as first step in the right direction. ICTs can greatly enhance the learning process, but teachers alone cannot cope with the vast amount of available information. The greater degree of 
specialisation could potentially increase the gap between frontier research and the classroom. PSAs are a potential solution, as we have discussed above.

\section{References}

Carlin, W. (2013), Economics explains our world -but economics degrees don't, The Financial Times, November 17, 2013.

URL: http://core-econ.org/wendy-carlin-in-the-ft-teaching-what-matters-in-economics/

Crafts, N.G, Bakker G., Michie R, Leuning T, Tennet N, Owen N and K. Hartley (2010). Learning from some Britain's successful sector: a historical analysis of the role of government. BIS Economic Papers 6.

Eichengreen, B. (2011), Economic History and Economic Policy, Presidential address to the Annual Meeting of the Economic History Association, Boston, MA, September 2011.

URL: http://eml.berkeley.edu/ eichengr/EHA Pres Add 9-9-11.pdf

Jordan, K. (2013). MOOC Completion Rates: The Data.

URL: http://www.katyjordan.com/MOOCproject.html

Palafox, J. (ed.) (2014). Los Tiempos Cambian: Historia de la Economía, Valencia: Tirant Humanidades. 